Peste Journal of Engineering Science and Technology Review 8 (3) (2015) 130-135

Research Article

\title{
Examination of Industrial Symbiosis Potential Interactions in an Industrial Area Of NE Greece
}

\author{
G. Gaidajis* and I. Kakanis
}

Department of Production Engineering and Management, School of Engineering, Democritus University of Thrace, 67100, Xanthi, Greece

Received 12 January 2014; Accepted 20 March 2015

\begin{abstract}
This paper considers the potential contribution of Industrial Symbiosis in fostering environmental and economical benefits in the area of Nea Karvali, Kavala, Greece. Industrial Symbiosis describes the mutualistic interaction of different industries for beneficial reuse of waste flows or energy cascading that results in a more resource-efficient production system and fewer adverse environmental impacts. Results from the case study presented in this paper, show that the implementation of symbiotic relationships in the industrial area under study, would lead to significant environmental benefits (GHG reduction, reduction on natural sources consumption) and would give a boost to the local economical sector by developing new business opportunities.
\end{abstract}

Keywords: industrial ecology, industrial symbiosis, eco-industrial parks, phosphoric fertilizer industry, hydrocarbon exploitation

\section{Introduction}

Sustainability and Sustainable Development (SD) is a difficult and complex issue (Munier, 2005) that requires a lot of attention and social awareness. Many definitions have been proposed, although one of the most widely accepted is found in the Brundland report (World Commission on Environment and Development,1987). It states that: Sustainable development is development that meets the needs of the present without compromising the ability of future generations to meet their own needs. One more definition that provides a methodology to follow to reach sustainability is given by Veiderman, stating that "sustainability is a vision of the future that provides us with a road map and help us focus our attention on a set of values and ethical and moral principles by which to guide our actions" (Viederman, 1993).

To address the issue of sustainable development of industrial regions, several theories and approaches such as Industrial Ecology (IE) and its tools, are being researched, investigated, implemented and practiced.

Industrial Ecology is defined by Graedel as "..the means by which humanity can deliberately and rationally approach and maintain sustainability, given continued economic, cultural, and technological evolution. The concept requires that an industrial system be view not in isolation from its surrounding systems, but in concert with them. It is a systems view in which one seeks to optimize the total materials cycle from virgin material, to finished material, to component, to product, to obsolete product, and to ultimate disposal. Factors to be optimized include resources, energy, and capital" (Graedel,1994). Another definition is provided by Boons et al., stating that "Industrial ecology is the study

* E-mail address: geogai@pme.duth.gr ISSN: 1791-2377 @ 2015 Kavala Institute of Technology. All rights reserved. of the material and energy flows resulting from human activities. This study provides the basis for developing approaches to close cycles in such a way that ecological impact of these activities is minimized" (Boons et al, 2009).

According to Chertow, IE address three levels: "facility or firm", "inter-firm" and "regional/global" (Chertow,2000). Within this approach, Industrial Symbiosis (IS) can be seen as part of IE on the "inter-firm" level (Jacobsen, 2006). Furthermore, IS and eco-industrial networking are presented as IE tools for implementing and applying IE in industrial regions, as shown in the Figure 1 below (Lifset, Graedel,2002).

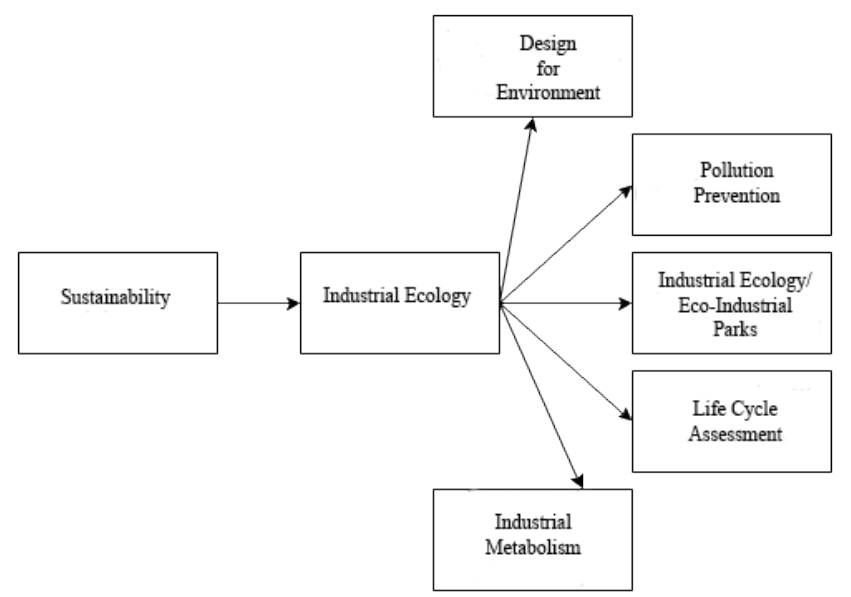

Fig 1. Different Levels of Industrial Ecology (Chertow,2000)

Industrial Symbiosis (IS) aims at "engaging traditionally several separate firms and industries in a collective approach to competitive advantage involving physical exchange of materials, energy, water, and by-products" (Chertow, 2000). Within this concept, the key elements to IS 
are defined as "collaboration", "synergistic possibilities offered by geographic proximity" and "co-located firms".

Eco-industrial parks are identified as concrete realizations of IS (Chertow, 2000). Based on this, several definitions of EIPs as a case of IS are presented. According to the U.S. EPA (1995), an eco-industrial park is defined as: "A community of manufacturing and service businesses seeking enhanced environmental and economic performance through collaboration in managing environmental and resource issues including energy, water, and materials. By working together, the community of businesses seeks a collective benefit that is greater than the sum of the individual benefits each company would realize if it optimized its individual performance only".

Based on the theoretical issues mentioned above an IS case study was conducted for the area of Nea Karvali, in NE Greece.

\section{Description of the Industrial Area Under Study}

The area of Nea Karvali was chosen, as it is known for its important industrial activity in Greece. This case study focuses not only on the potential symbiotic relationships, but also on developing the industrial activity in the local region, with proposals based on the principles of IE and on the experience gained from other symbiotic projects from all over the world.

The most important industrial areas of northern Greece according to number of industries residing in each area are presented in Table 1.

Table 1:.Industrial areas of Northern Greece

\begin{tabular}{lccc}
\hline Industrial Area & $\begin{array}{c}\text { Founded } \\
\text { in }\end{array}$ & $\begin{array}{c}\text { Number of } \\
\text { industries }\end{array}$ & $\begin{array}{c}\text { Hazardous } \\
\text { Waste }\end{array}$ \\
\hline Thessaloniki & 1965 & 569 & Yes \\
Ioannina & 1976 & 150 & Yes \\
Komotini & 1976 & 142 & Yes \\
Drama & 1975 & 73 & No \\
Kavala (Nea & 1977 & 53 & Yes \\
Karvali) & & & \\
Serres & 1978 & 52 & No \\
Alexandroupoli & 1980 & 20 & Yes \\
\hline
\end{tabular}

Source: Mourtsiadis, 2010

\subsection{Existing industrial activity}

The major industrial activities in the area are those of an oil exploitation and extraction company (OEEC) and of a fertilizer industry (FI).

\section{Oil exploitation and extraction company (OEEC)}

The only company extracting hydrocarbons in Greece, i.e. oil and natural gas is located in the area. This uniqueness ranks Greece on the list of oil-producing countries and causes the general public interest in the development of technical and operational activities.

The land infrastructure is located approximately $3 \mathrm{~km}$ east of the village of Nea Karvali alongside the coast (Figure 2 ), and occupies an approximate area of $26 \mathrm{Ha}$ including production facilities and outdoor storage facilities. Marine facilities consist of gas production off shore platform and rigs for off shore production of crude oil.

The production process is comprised of:

- Stabilization of crude oil (production capacity: $27,000 \mathrm{bbls} / \mathrm{d}$ (barrels per day).
- Treatment of sour gas (production capacity: $333,000 \mathrm{Nm}^{3} / \mathrm{d}$.

- Production of liquid or solid sulfur (production capacity: $478 \mathrm{t} / \mathrm{d}$ (metric tons per day).

- Production of electricity for own consumption (production capacity: 17.67 MWe (Megawatt electric: electric output of a power plant in megawatt)).

- Liquid natural gas production (production capacity $264 \mathrm{~m}^{3} / \mathrm{d}$ ).

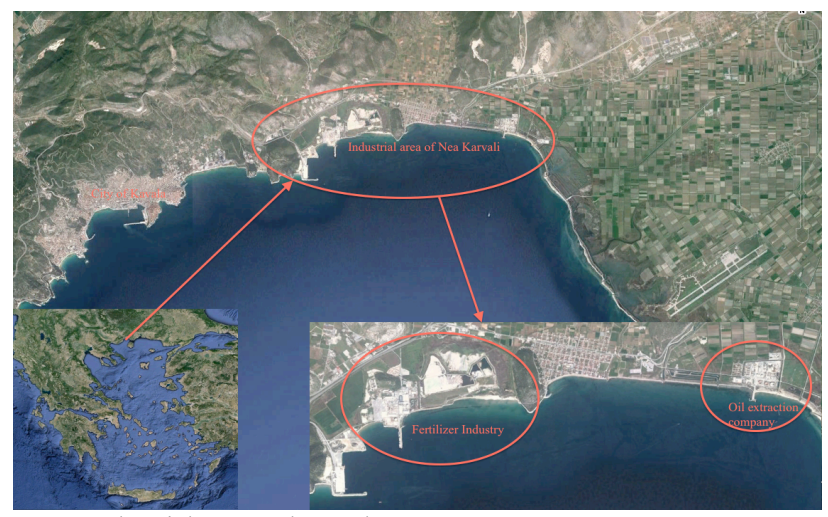

Fig 2. Industrial area under study

Fertilizer industry (FI)

The FI is engaged in the production of ammonia, acids and fertilizers since 1965 . The facilities of the company cover an approximate area of $258 \mathrm{Ha}$ (see Figure 2) and include five production units, namely:

- Ammonia production unit.

- Nitric acid and nitric fertilizers production unit.

- Sulphuric acid production unit.

- Phosphoric acid production unit.

- Compound fertilizer production unit.

The facility is listed in the European Pollutant Release and Transfer Register with the 2012 data summarized in the Table 2 below.

Table 2:.Pollutant releases of the FI in 2012

\begin{tabular}{lrl}
\hline Pollutant name & Total (t) & Method \\
\hline Releases to air & & \\
Carbon dioxide (CO2) & 180,000 & Measured \\
Fluorine and Inorganic & 7.75 & Measured \\
compounds (as HF) & & \\
Nitrous Oxide (N2O) & 990 & Estimated \\
Ammonia & 20.8 & Measured \\
Nitrogen oxides & 205 & Measured \\
\hline Releases to water & & \\
Fluorides (as total F) & 41 & Measured \\
Total nitrogen & 327 & Measured \\
Total phosphorus & 48 & Measured \\
Zinc and compounds (as Zn) & 0.18 & Calculated \\
\hline
\end{tabular}

Source: http://prtr.ec.europa.eu/

\section{Results and Discussion}

Based on the production processes of the industrial activities mentioned above the following symbiotic actions may be proposed (summarized in Table 3 below). 
Table 3:.Potential products/by-product exchanges

\begin{tabular}{|c|c|c|}
\hline $\begin{array}{l}\text { Product/ By- } \\
\text { product }\end{array}$ & From & Potential use \\
\hline $\mathrm{CO}_{2}$ & FI & $\begin{array}{l}\text { - Use for EOR (Enhanced } \\
\text { Oil Recovery) } \\
\text { - Greenhouse } \mathrm{CO}_{2} \\
\text { enrichment }\end{array}$ \\
\hline Sulfuric acid & FI & - Supply to OEEC \\
\hline Phosphogypsum & FI & $\begin{array}{l}\text { - Construction material } \\
\text { - Road construction } \\
\text { material } \\
\text { - Environmental use } \\
\text { (quarries, soil } \\
\text { remediation etc.) }\end{array}$ \\
\hline Wastewater & $\begin{array}{l}\text { FI and/or } \\
\text { OEEC }\end{array}$ & $\begin{array}{l}\text { - Fishfarms (heating) } \\
\text { - Greenhouse (heating) } \\
\text { - Public utility buildings } \\
\text { (heating) } \\
\text { - LNG terminal station } \\
\text { (regasification of LNG) }\end{array}$ \\
\hline Liquid Sulfur & OEEC & $\begin{array}{l}\text { - Use for sulfuric acid } \\
\text { production }(\mathrm{FI})\end{array}$ \\
\hline Petroleum Sludge & OEEC & $\begin{array}{l}\text { - Supply to road } \\
\text { construction companies } \\
\text { for tar production }\end{array}$ \\
\hline Natural Gas & $\begin{array}{l}\text { Future } \\
\text { LNG } \\
\text { plant } \\
\text { (under } \\
\text { study) }\end{array}$ & - Supply to OEEC (fuel) \\
\hline
\end{tabular}

\subsection{Carbon dioxide from FI to OEEC}

Carbon dioxide $\left(\mathrm{CO}_{2}\right)$ is one of the most significant byproducts of the FI, produced during the production process of ammonia. The amount of $\mathrm{CO}_{2}$ released to the atmospheric environment was measured to be $180 \mathrm{kt}$ in 2012 (see Table 2). Currently there is no $\mathrm{CO}_{2}$ capture technology supported in the facilities, meaning that the existing amounts of $\mathrm{CO}_{2}$ are emitted directly to the atmosphere.

Due to the environmental significance of this by-product, as $\mathrm{CO}_{2}$ is recognized as one of the major greenhouse gases ( $\mathrm{GHG}$ ), the implementation of a $\mathrm{CO}_{2}$ capture technology is considered necessary. The $\mathrm{CO}_{2}$ capture technologies are distinguished by the processing phase in which the $\mathrm{CO}_{2}$ is isolated (Koukouzas et al, 2010). Therefore we have:

- Capture technologies before combustion

- Capture technologies after combustion

- Combustion with high concentration of $\mathrm{O}_{2} / \mathrm{CO}_{2}$

- Innovative applications

The proposed $\mathrm{CO}_{2}$ capture technology for $\mathrm{FI}$ is the $\mathrm{CO}_{2}$ absorption by ammonia. This method called chilled ammonia process was developed in 2007 (Mongstad Technology Center, The Royal Norwegian Ministry of Petroleum and Energy, 2007). The FI already has an ammonia production unit, so it would be in their benefit to invest in this method.

OEEC could use the captured $\mathrm{CO}_{2}$ to produce more oil and gas with the enhanced oil recovery method (EOR). EOR is a term used to describe a set of processes intended to increase the production of oil beyond what could normally be extracted when using conventional oil production methods. While traditional oil production can recover up to $35-45 \%$ of the original oil in place, the application of an
EOR technique, typically performed towards what is normally perceived to be the end of the life of an oilfield, may produce an additional 5-15\% (Tzimas et al, 2005).

One of the EOR techniques is based on $\mathrm{CO}_{2}$ utilization. The injection of $\mathrm{CO}_{2}$ at high pressure into an oil reservoir can mobilize oil that has not been extracted using traditional methods. Furthermore, a fraction of the injected $\mathrm{CO}_{2}$ remains stored underground, contributing to $\mathrm{CO}_{2}$ removal from the atmosphere and combating therefore to global climate change through greenhouse gas removal (Tzimas et al, 2005).

The reservoirs in the area of Prinos, are a potential area for the implementation of the EOR method with total capacity of $17 \mathrm{Mt}$. Based on the evidence from other studies, the implementation of EOR method by the OEEC can be translated to $5-15 \%$ of additional oil, which is a significant number of barrels of oil.

\subsection{Sulfuric acid from FI to OEEC}

FI produces $375 \mathrm{kt} /$ year of sulfuric acid, which is used as a raw material for the production of phosphoric acid and compound fertilizers. Overall the total needs of sulfuric acid for the production processes of FI is up to $315 \mathrm{kt} / \mathrm{y}$. Annually there is a $60 \mathrm{kt}$ excess of sulfuric acid stored for future use.

A part of this excessive amount of sulfuric acid could be supplied to the OEEC, that uses sulfuric acid as utility material. The OEEC needs annually $9,5 \mathrm{kt}$ of sulfuric acid, or $16 \%$ approximately of the excess of sulfuric acid produced by FI.

\subsection{Phosphogypsum (PG) reuse}

Besides $\mathrm{CO}_{2}$, phosphogypsum is another significant byproduct from the FI. It is produced during the production process of phosphoric fertilizers, in the phase of phosphorate and sulfuric acid reaction. The total amount of this byproduct is up to $300 \mathrm{kt} /$ year. Currently the FI is storing all the amount of this by-product in the facilities and is looking into finding the most suitable and efficient way of phosphogypsum reuse.

PG is an inorganic residue, containing, among others, heavy metals and radioactive elements, which in large quantities can cause chemical and radioactive pollution. The source of radioactivity in $\mathrm{PG}$ is due to the presence of uranium and various products of uranium decomposition (such as radium). Therefore, all the proposed solutions for reusing $\mathrm{PG}$, require control of the material and adoption of appropriate measures to proper and safe usage (Tayibi et al, 2011).

The potential reuses of PG are summarized below:

- Use in production of construction materials

- Use in cement industry to produce Portland type cement (Smadi et al, 1999).

$\circ \quad$ Use in ceramic and brick industry (similar method is applied successfully in China and India) (Shen, 2010).

- Use in gypsum plasterboard production (in the standards of Gyproc in Kalundborg, Denmark) (Brings Jacobsen, 2006).

- Use as raw material for the production of fertilizers (Abu-Eishah et al, 2000).

- Use in environmental applications. 
- Soil amendment (following the example of Kwinana eco-industrial park) (Beers et al, 2007).

- Use as a filler material for rehabilitation of abandoned quarries.

- Use in road construction and in rail network construction.

\subsection{Industrial wastewater reuse}

Industrial wastewater reuse is a typical example of a symbiotic relationship in an Eco-industrial park. Companies invest in wastewater treatment and reuse not only to comply with effluent standards, but also because product recycling and raw material recovering benefit a company's image as well as the bottom line (Visvanathan et al, 2004).

In this case study, potential case scenarios for reusing the wastewater both from OEEC and FI were examined. OEEC produces approximately $1,300 \mathrm{~m}^{3} / \mathrm{hr}$ of industrial wastewater, while FI produces $100-120 \mathrm{~m}^{3} / \mathrm{hr}$, at a temperature of $50-60{ }^{\circ} \mathrm{C}$. Given its elevated temperature, the wastewater could be used for heating local facilities such as greenhouses and fish farms and/or public utility buildings, contributing to the societal image of the facilities.

Taking into account the scheduled future industrial activities in the area involving the operation of a floating regasification LNG terminal, in order to regasify the LNG, the necessary heat amount is taken from sea water, which is subsequently discharched cooler and chlorinated to the sea. Therefore, industrial wastewater both from OEEC and FI could partially replace the sea water utilization for $\mathrm{LNG}$ regasification, contributing positively to energy and resources savings.

The potential scenarios for industrial wastewater reuse are summarized in Fig 3.

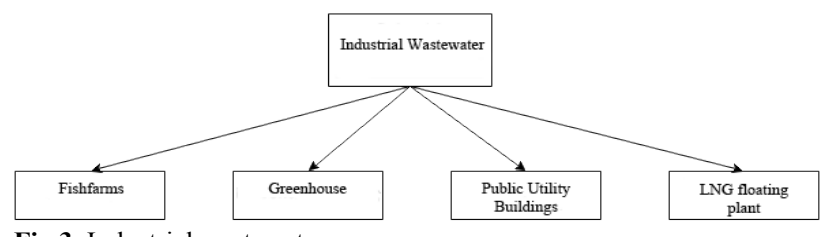

Fig 3. Industrial wastewater reuse

\subsection{Fish farm development}

Fishing is a very important economic activity in the wider area of Kavala. The northern Aegean fish field has been recording a sharp production decrease the last decade due to fishing intensification and other anthropogenic reasons outside the scope of this study. Thus as a countermeasure the development of fish farms and/or the support of the existing fish farms in the vicinity of FI and OEEC is considered, following the successful example of fish farming in Kalundborg, Denmark (Brings Jacobsen, 2006). The main issue for fish farming is the control of the water temperature during winter and summer months. A closed circuit with the warm wastewater from OEEC and FI could be used for heating the water of fish farms during winter time. On the other hand, in the case that the LNG floating plant is materialized, the discharged cool water could be used, if needed, for cooling the fish farm waters during summer months.

\subsection{Liquid sulfur from OEEC to FI}

FI needs sulfur as a raw material for the production of sulfuric acid. More specifically the need for liquid sulfur is quantified up to $130 \mathrm{kt} /$ year. OEEC produces liquid sulfur as a main product, to an annual capacity of $33 \mathrm{kt} / \mathrm{y}$. Even though the annual amount of liquid sulfur produced from OEEC does not cover the annual needs of FI, it could be a significant contribution of material exchange towards industrial symbiosis and sustainable development.

\subsection{Reuse of petroleum sludge}

Petroleum sludge, a mixture of heavy hydrocarbons, asphaltenes and mineral solids, is a solid waste resulting from cleaning activities during the maintenance of the OEEC facilities. The total amount of petroleum sludge in the OEEC facilities amounts to $560 \mathrm{~m}^{3}$. Materials derived from the petroleum refining are used, after processing, in road works. More specifically in our case the petroleum sludge can be used to produce tar which is a core layer material in road construction and after further treatment, can be used for asphalt production (pandora.meng.auth.gr). It is proposed therefore to direct the petroleum sludge of OEEC to relevant activities.

\subsection{Greenhouse development with $\mathrm{CO}_{2}$ enrichment}

$\mathrm{CO}_{2}$ enrichment in greenhouses is a common procedure to enhance photosynthesis and to increase crop yield. In northern Europe it is now routinely used in tomato production and has increased yields by $30-40 \%$. Elevated $\mathrm{CO}_{2}$ concentration also increases the optimal growth temperature and can therefore be beneficial in warm climates from this point of view. On the other hand, in warm climates due to the increased ventilation needs of greenhouses in order to reduce air temperature and/or humidity, the $\mathrm{CO}_{2}$ is removed as well, resulting in decreased $\mathrm{CO}_{2}$ levels (Amir et al, 2005), which ultimately increase the financial cost of the enrichment.

In order to avoid the conflict between $\mathrm{CO}_{2}$ enrichment and ventilation processes, it is necessary to determine the season of enrichment. It is better to choose a season when the need for ventilation is limited, i.e. the period between mid fall and the start of spring. Furthermore it is necessary to determine the amount of $\mathrm{CO}_{2}$ introduced to the greenhouse atmosphere. The minimum amount required from the crop in order to induce photosynthesis is $5 \mathrm{~g} / \mathrm{m}^{2} / \mathrm{h}$, even though larger amounts of $\mathrm{CO}_{2}$ are often introduced, reaching to approximate amounts of $20 \mathrm{~g} / \mathrm{m}^{2} / \mathrm{h}$. The available quantities of $\mathrm{CO}_{2}$ are higher that the amount plants could intake and could maintain high $\mathrm{CO}_{2}$ concentrations, even during greenhouse ventilation periods (Nederhoff, 2004).

As mentioned above, the annual quantities of $\mathrm{CO}_{2}$ produced by FI reach approximately $180 \mathrm{kt}$. As a result, those quantities can support green houses of a significant size given the range of the required $\mathrm{CO}_{2}$ quantities (5-20 $\mathrm{g} / \mathrm{m}^{2} / \mathrm{h}=44-175 \mathrm{~kg} / \mathrm{m}^{2} /$ year $=0,4-1,7 \mathrm{kt} / \mathrm{ha} /$ year) to promote photosynthesis and sustain the health of plants. Moreover, the available $\mathrm{CO}_{2}$ annual quantities are sufficient enough to be used both for enhanced oil recovery in OEEC and for $\mathrm{CO}_{2}$ enrichment in spacious greenhouse installations.

\subsection{Liquid Natural Gas from LNG floating plants to OEEC}

Another synergy that could potentially take place is the utilization of the boiled off LNG quantities to the steam generating boilers of OEEC. The utilization of natural gas in OEEC terminated recently due to safety and financial reasons. Should the LNG terminal and regasification plant is implemented, OEEC, could benefit through the potential supply of liquid natural gas. 


\subsection{Underground storage of natural gas}

The natural gas reserves in the reservoirs in the OEEC reservoirs are heading for exhaustion. These geological structures have successfully kept their hydrocarbon deposits trapped for million of years and therefore are particularly suitable for storing natural gas. Nowadays, depleted reservoirs are by far the most popular way of underground natural gas storage and the least expensive to develop and operate (www.eia.gov).

The final decision in order to develop this project depends on geographical and economical factors, thus thorough investigation is needed in order to proceed with such a synergistic idea. Figure 4 shown below, summarizes all the proposed synergistic flows and interactions in the industrial symbiosis case study examined here.

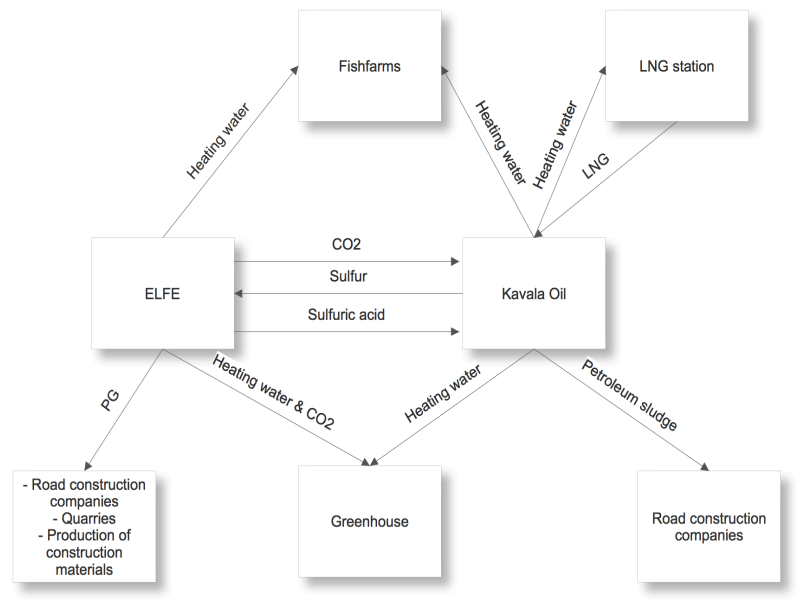

Fig 4. Proposed symbiotic relationships

\section{Conclusions}

In this paper the potential symbiotic actions between two industrial activities located in NE Greece were examined. The industrial activities examined were oil exploitation and extraction (OEEC) and a fertilizer industry (FI). Based on the production processes and the specific characteristics of the industrial activities the following major symbiotic actions are proposed in order to increase the utilization of the material flows and to decrease the combined environmental footprint of the industrial site:

- Focus should be drawn to by-products that occur in significant amounts both for their immediate and proper management and for the development of new activities in the local region, such as PG (first raw material for brick and plasterboard manufacturing, filler material for the local quarries).

- The construction of a greenhouse that will boost the agricultural production in the region and could potentially be suitable for symbiotic relationships (wastewater reuse, $\mathrm{CO}_{2}$ enrichment).

- An immediate solution for capturing and reusing $\mathrm{CO}_{2}$ should be found, in order to reduce the environmental impact from greenhouse gases.

- The creation of a network that ensures the reuse of industrial wastewater, both for industrial and for social (heating for public utility buildings) use.

Quantifying the environmental benefits from such a project in the area of Nea Karvali, we can see that there will be a significant reduction of greenhouse gases $(200 \mathrm{kt} / \mathrm{yr}$ of $\mathrm{CO} 2$ ), reduced environmental impacts from storing hazardous by-products (phosphogypsum), and reduced consumption of first raw materials (reuse of approximately 2 $\mathrm{Mt} / \mathrm{yr}$ of water).

In conclusion, it is safe to say that there are encouraging prospects for adopting already proven practical tools of Industrial Ecology, in Greece. Specifically, the prospects of such a project in the area of Nea Karvali are high as it could be beneficial for the development of an already important industrial area.

Therefore the present study can be characterized as an initial effort to assess the potential increase of symbiotic actions and improvement of the overall environmental performance of the specific industrial area. In order to proceed in a more elaborated study, further data related with the production processes, the environmental releases and the financial performance are required.

\section{References}

1. Abu-Eishah, Samir I., Bani-Kananeh, Ali A., Mamdouh, A. (2000), K2SO4 production via the double decomposition reaction of KCI and phosphogypsum, Chemical Engineering Journal 76, 197-207

2. Amir, R., Teitel, M., Shemer, L. (2005), $\mathrm{CO}_{2}$ Enrichment in a Fan-Ventiliated Greenhouse under Different Ventilation Modes, Israel, Acta Horticulturae, Vol.2 ,619-624

3. Beers, D., Corder, G., Bossilkov, A., Berkel, R. (2007), Industrial Symbiosis in the Australian Minerals Industry - The cases of Kwinana and Gladstone, Journal of Industrial Ecology, Vol.11, No. 1, 55-72

4. Boons, F., Howard-Grenville, J. (2009), The Social Embeddedness of Industrial Ecology, Northampton MA, USA, Edward Elgar

5. Brings Jacobsen, N. (2006), Industrial Symbiosis in Kalundborg, Denmark - A Quantitative Assessment of Economic and Environmental Aspects, Journal of Industrial Ecology, Vol.10, No.1-2, 239-255

6. Chertow, M. R. (2000), Industrial symbiosis: literature and taxonomy. Annual Review of Energy and Environment, 25, 313-
337.

7. Graedel, T. E. (1994), Industrial ecology: definition and implementation. In Industrial Ecology and Global Change, Cambridge, U.K.: Cambridge University Press.

8. http://pandora.meng.auth.gr/dewam/index.php/eng/Diachehirise/ Hasphaltos-kai-orykthe-phissa

9. http://prtr.ec.europa.eu/FacilityDetails.aspx?FacilityId=14239

10. http://www.eia.gov/pub/oil_gas/natural_gas/analysis_publication s/storagebasics/storagebasics.html

11. Huber, J. (2000), Towards Industrial Ecology: Sustainable Development as a Concept of Ecological Modernization, Journal of Environmental Policy and Planning, Vol.2, No.4, 269-285

12. Koukouzas N., Stogiannis P., Kakaras Em. (2010), Storage of carbon dioxide in underground geological reservoirs, Chemical Chronicles, General Publication, Vol. 72, 16-20

13. Lifset, R. J., Graedel, T. E. (2002), Industrial ecology: goals and definitions, in handbook of industrial ecology, edited by R. U. Ayres and L. W. Ayers, Cheltenham, U.K.: Edward Elgar.

14. Mourtsiadis A. (2010), Hazardous waste management in industrial areas, lecture on "Hazardous waste management - 
present and possibilities", Athens.

15. Munier N. (2005), Introduction to Sustainabilty: Road to a Better Future, Springer, Ottawa, Ontario, Canada

16. Nederhoff, E. (2004), Carbon Dioxide Enrichment, Practical hydroponics \& Greenhouses, May/June, 50-59

17. Shen, C.X. (2010), Characteristics of gypsum block \& prospect of gypsum block industry in China, the 2010 China International Symposium on Phosphogypsum Comprehensive Utilization Technology Development and Promotion, June 9-10, 2010, Beijing, China

18. Smadi, M.M., Haddad, R.H., Akour, A.M. (1999), Potential use of phosphogypsum in concrete, Cement and Concrete Research, Vol.29, Issue 9, 1419-1425

19. Tayibi, H., Gasco, C., Navarro, N., Lopez-Delgado, A., Choura, M., Alguacil, F., Lopez, F. (2011), Radiochemical Characterization of Phosphogypsum for Engineering Use, Journal of Environmental Protection, Volume 2, 168-174
20. The Royal Norwegian Ministry of Petroleum and Energy (2007), European CO2 Test Centre Mongstad, Norway, European Commision

21. Tzimas, E. , Georgakaki, A., Garcia Cortes, C., Peteves, S.D. (2005), Enhanced Oil Recovery using Carbon Dioxide in the European Energy System, Patten, Netherlands, European Commision

22. US EPA (1995), Field-book for the development of eco-industrial parks, Oakland, CA: Indigo Development Company

23. Viederman, S. (1993). The economics and economy of sustainability: Five capitals and three pillars. Talk delivered to Delaware Estuary Program. Available from Noyes Foundation, New York.

24. Visvanathan, C., Asano, T. (2004), The Potential for Industrial Wastewater Reuse, Encyclopedia of Life Support Systems, Wastewater recycle, reuse, and reclamation

25. WCED (World Commission on Environment and Development) (1987), Our common future. World Conference on Environment and Development. Oxford University Press, Oxford 